\title{
The Evaluation of Renal Osteodystrophy in Patients on Hemodialysis by Biochemical and Radiological Methods
}

\author{
Hemodiyaliz Hastalarında Renal Osteodistrofinin Radyolojik ve Biyokimyasal \\ Yöntemlerle Değerlendirilmesi
}

\begin{abstract}
Sibel Mandıroğlu, Ece Ünlü*, Deniz Aylı**
Ankara Physical Therapy and Rehabilitation Education And Research Hospital, Department of Physical Medicine And Rehabilitation, Ankara, Turkey *DIskapı Yıldırım Beyazıt Education and Research Hospital, Department of Physical Medicine and Rehabilitation, Ankara, Turkey

**Diskapı Yıldırım Beyazıt Education and Research Hospital, Department of Nephrology, Ankara, Turkey
\end{abstract}

\section{Summary}

\begin{abstract}
Aim: We planned this study in order to evaluate the radiological and biochemical parameters that may be useful in the early diagnosis of renal osteodystrophy in the patients with chronic renal failure, prospectively.

Meterial and Methods: In this study, 50 cases on hemodialysis due to chronic renal failure were included and 50 cases without renal and bone pathology were included as control group. Serum levels of calcium, phosphate, alkalen phosphatase, $\beta m$, osteocalcin (BGP) and intact parathormon (iPTH) were measured. Right hand graphies of both case and control groups were taken by magnifying techniques. Bone mineral densities (BMD) of lumbar vertebra and femur neck were calculated by DEXA method. Results: The average disease duration and the average of duration of hemodialysis of cases were $8.38 \pm 5.61$ years and $6.9 \pm 4.01$ years, respectively. There were significant differences between case and control groups in all biochemical parameters, except calcium levels $(p<0.05)$. There were a negative correlation between PTH and BMD $(r=-0.4, p<0.05)$, and pozitif correlations between iPTH and BGP ( $r=0.6$, $p<0.05)$, and between PTH and $\beta-\mathrm{m}(r=0.5, p<0.05)$. A low level negative but statistically significant correlation between dialysis duration and femur neck bone mineral density was determined $(r=0.2, p<0.05)$. There were positive correlations between dialysis duration and PTH levels $(r: 0.3, p<0.05)$, and between dialysis duration and $\beta_{2} m(r=0.4, p<0.05)$. In the hand graphies, osteopenia, subperiostal resorption, radial artery calcification and endoosteal resorption were seen. Ostepenia was determined in $80 \%$ of our cases, however, subperiostal resorption was found in 58\% of patients. The cases that had iPTH levels over than $200 \mathrm{pg} / \mathrm{ml}$ and cases that have osteopenia have sensitivity of $93 \%$ and spesifity of $92 \%$ for RO diagnosis. Sensitivity and spesifity for high iPTH-BGP levels were $90.3 \%$ and $87 \%$, respectively. Sensitivity and spesifity in the evaluation of high iPTH-subperiostal resorption were $83.9 \%$ and $84.2 \%$, respectively.
\end{abstract}

Conclusion: Measure of iPTH, BMD, BGP and evaluation of hand graphies may be used in early diagnosis and follow-up of RO. (Turkish Journal of Osteoporosis 2013;19: 7-11)

Key words: Bone mineral density, hemodialysis, renal osteodystrophy

\section{Özet}

Amaç: Bu çalışmada kronik böbrek yetmezliği olan olgularda renal osteodistrofinin erken tanısında faydalı olabilecek radyolojik ve biyokimyasal parametreleri prospektif olarak araştırmayı planladık.

Gereç ve Yöntem: Kronik böbrek yetmezliği nedeni ile hemodiyalize giren 50 olgu ve dahil edildi. Böbrek problemi ve kemik hastalığı olmayan 50 olgu kontrol grubu olarak çalışmaya dahil edildi. Serum kalsiyum, fosfor, alkalen fosfataz, $\beta$-microglobulin $(\beta \mathrm{m})$, osteokalsin (BGP), intact parathormon (iPTH) seviyeleri ölçüldü.Her iki grupta sağ el grafileri magnifiye teknikle çekildi. Lomber vertebra ve femur boyun kemik mineral yoğunluğu (KMY) DEXA yöntemi ile ölçüldü.

Bulgular: Olgularımızın ortalama hastalık süresi $8,38 \pm 5,61$ yıl, diyalize girme süresi $6,9 \pm 4,01$ yıldı. Kalsiyum dışındaki bütün biyokimyasal parametlerde olgu ve kontrol grubumuz arasında önemli derecede fark mevcuttu $(p<0,05)$.IPTH ve KMY arasında negatif korelasyon mevcuttu $(r=-0,4, p<0,05)$. IPTH ve BGP, IPTH ve $\beta_{2} m$ arasında pozitif korelasyon mevcuttu $(r=0,6, p<0,05),(r=0,5, p<0,05)$. Diyaliz süresi ve femur boyun KMY arasında istatistiksel olarak anlamll, düşük düzeyde negatif korelasyon mevcuttu $(r=0,2, p<0,05)$. Diyaliz süresi ve IPTH, diyaliz süresi ve $\beta m$ arasında pozitif korelasyon mevcuttu $(r=0,3, p<0,05),(r: 0.4, p<0,05)$. El grafilerinde osteopeni ve subperiostal resorbsiyon, radyal arter kalsfikasyonu ve endosteal resorbsiyon görüldü. Olgularımızın \%80'de osteopeni, \%58'de subperiostal resorbsiyon saptandı. IPTH seviyesi 200 pg/ml üzerinde

Address for Correspondence / Yazışma Adresi: Sibel Mandıroğlu MD, Ankara Physical Therapy and Rehabilitation Education And Research Hospital, Department of Physical Medicine and Rehabilitation, Ankara, Turkey Phone: +90 31231032 30-1345 E-mail: sblmandir@hotmail.com Received/Geliş Tarihi: 24.08.2012 Accepted/Kabul Tarihi: 30.01.2013 
olan olgular ve osteopenisi olan olgularda RO tanısı için sensitivite \%93, spesifite \%92'dü. Yüksek IPTH-BGP için sensitivite ve spesifite sırası ile \%90,3 ve $\% 87$ 'di. Yüksek IPTH-subperiostal resorbsiyon için ise sensitivite $\% 83,9$, spesifite $\% 84,2$ 'di.

Sonuç: IPTH, BMD, BGP ölçümleri ve el grafilerinin değerlendirilmesi RO’nin erken tanısı ve izleminde kullanılabilir. (Türk Osteoporoz Dergisi 2013;19: 7-11)

Anahtar kelimeler: Kemik mineral yoğunluğu, hemodiyaliz, renal osteodistrofi

\section{Introduction}

The number of patients with chronic renal failure (CRF) is increasing with the development of new diagnostic methods. Although the average life span of the patients with CRF has increased with treatment modalities such as hemodialysis and peritoneal dialysis, many complications began to be seen more frequently. Renal osteodystrophy (RO) is one of these complications and it causes mineral and bone metabolism impairment, and morbidity and mortality in most of patients (1-3). Osteitis fibrosa sistica, osteomalacia, skeletal abnormalities related to $\beta_{2}$ mikroglobulin $\left(\beta_{2} m\right)$, osteosclerosis and osteoporosis are histopatologically observed in RO (4). Hypocalcemia, phosphate retention, changes in vitamin D metabolism, decrease of PTH degradation, changes in calcium regulation are led to secondary hyperparathyroidism pathophysiologically. Increase of PTH levels results in rise of osteoclastic activity and bone resorption. Such an osteoclastic activity occurs in Haversian channels of cortical bone and subperiostal and endosteal surfaces. Cortical bone resorption occurs with PTH stimulated increased osteosit activity. Possible causes of osteoporosis in CRF include changes in vitamin $D$ levels, immobilisation and chronic protein deficiency. Hyperphosphatemia can be observed in the phases which the catabolism increases due to the protein metabolism and catabolism. RO which becomes clinically evident with cases like bone aches, myopathy, muscle cramps, calciphylaxis and skeleton deformities affects the life quality of the cases with CRF and causes serious mortality and morbidity (5). Bone biopsy is advised for definitive diagnosis but its usage is limited due to its invasive process (6). That's why evaluation of the current laboratory and scanning procedures and not skipping the RO diagnosis are of the importance (7). For this reason in this prospectively planned study, we aimed to investigate the noninvasive methods that can be useful in early diagnosis of RO.

\section{Material and Method}

Fifty patients on chronic hemodialysis were included in this study which was planned prospectively in order to examine RO with noninvasive methods in the patients on hemodialysis. Fifty voluntary subjects without any primary renal problem and bone disease were also included in this study as a control group. The physical examinations of members of both patient and control groups were performed. The serum calcium, phosphorus, alkalen phosphatase, $\beta_{2}$ mikroglobulin $\left(\beta_{2} \mathrm{~m}\right)$ and intact parathormon (iPTH) levels of both groups were measured. Osteocalcin (BGP) levels were determined by Enzyme-linked immunosorbent assay (ELISA) method.

Right hand graphies of both case and control groups were taken by magnifying techniques. Thereafter, bone mineral dansities were measured from lumbar vertebra and femur neck by Dual energy X-ray absorptiometry (DEXA) method.

T-test, chi-square test and Pearson correlation analysis were used for statistical analysis of study parameters of patient and control groups. Statistically $p<0.05$ value was considered as significant.

\section{Results}

The average age of our cases; 30 of whom were male, whereas 20 of whom were female; was $46.4 \pm 11.5$ (19-69) years. The average disease duration of our cases was 8.38 \pm 5.61 (1-23) years and the duration of hemodialysis was $6.9 \pm 4.01$ (1-16) years. Thirty-one members of the control group were male and 19 of them were female, and their average age was $45.8 \pm 11.5$ (25-66) years. "There was no significant difference between case and control groups in age and sex distribution ( $p>0.05$ ). The distribution of cases according to etiologies were shown at Graphic 1.

The average and standart deviation values of alkalen phosphatase (ALP), calcium, phosphorus, $\beta_{2}$-microglobulin, osteocalcin (BGP) and parathormon of cases and controls were given at Table 1. There was significant difference between case and control groups in all biochemical parameters, except calcium levels $(p<0.05)$.

The bone mineral densities of femoral neck and lumbar vertebra were measured in both groups; and Z-value and T-value were calculated. Both of lumbar vertebra (BMDL) values and femoral neck (BMDF) values have shown significant difference between two groups $(\mathrm{p}<0.05)$ (Table 2).

The correlation of $\mathrm{PPTH}$ with BMD, BGP, ALP and $\beta_{2}$ m were examined, there was negatif correlation between $\mathrm{iPTH}$ and $\operatorname{BMD}(r=-0.4, p<0.05)$, whereas, there were positive correlations between iPTH and BGP $(r=0.6, p<0.05)$, and between PTH and $\beta_{2} \mathrm{~m}(\mathrm{r}=0.5, \mathrm{p}<0.05)$.

When the correlations of dialysis duration with $B M D F, B M D L$, iPTH, BGP, ALP and $\beta_{2} \mathrm{~m}$ were evaluated, there was low level

Table 1 . The values of biochemical parameters $(x \pm S D)$ of cases and controls

\begin{tabular}{|l|l|l|l|}
\hline & Case $(\mathbf{n}=\mathbf{5 0})$ & Control $(\mathbf{n}=\mathbf{5 0})$ & $\mathbf{P}$ \\
\hline$A L P(u / l)$ & $137.4 \pm 68$ & $89.2 \pm 22$ & $p<0.05$ \\
\hline$C a(m g / d l)$ & $9 \pm 0.7$ & $9.5 \pm 0.5$ & $p>0.05$ \\
\hline$P(m g / d l)$ & $5.6 \pm 1.8$ & $3.4 \pm 0.6$ & $p<0.05$ \\
\hline$\beta_{2} m(m g / d l)$ & $21.27 \pm 11.80$ & $1.26 \pm 0.24$ & $p<0.05$ \\
\hline$B G P(\mu \mathrm{g} / \mathrm{L})$ & $124.36 \pm 42.88$ & $13.52 \pm 9.12$ & $p<0.05$ \\
\hline$P T H(\mathrm{pg} / \mathrm{ml})$ & $202 \pm 131$ & $30.5 \pm 10.4$ & $p<0.05$ \\
\hline
\end{tabular}


but statistically significant negative correlation between dialysis duration and BMDF $(r=-0.2, p<0.05)$, whereas, there were positive correlation between dialysis duration and PTH $(r=0.3, p<0.05)$ and between dialysis duration and $\beta_{2} \mathrm{~m}(\mathrm{r}=0.05, \mathrm{p}<0.05)$ (Table 3). The right hand (dominant hand) graphies of all patients in both case and control groups were evaluated radiologically (Figure 1). The hand graphies were prepared by a special magnifying technique. Osteopenia and subperiostal resorption were found to be most frequent findings. Less frequently, radial artery calcification and endosteal resorption were determined. Osteopenia was found in $80 \%$ of cases, and subperiostal resorption were determined in $58 \%$ of cases (Table 4). Subperiostal resorption were frequently determined at radial, ulnar and radioulnar sites of phalanges (Graphic 2).

For diagnosis of RO occuring as a result of secondary hyperparathyroidism, we investigated the sensitivity and specificity values of parameters evaluated in our cases. When we take into account osteopenia cases which have iPTH values

Table 2. The comparision of DEXA BMD results of cases and controls

\begin{tabular}{|l|c|c|c|}
\hline & $\begin{array}{c}\text { Case } \\
(\mathbf{n}=\mathbf{5 0})\end{array}$ & $\begin{array}{c}\text { Control } \\
(\mathbf{n}=\mathbf{5 0 )}\end{array}$ & $\mathbf{P}$ \\
\hline Femur Total Z score & $-1.4 \pm 0.8$ & $0.01 \pm 0.8$ & $p<0.05$ \\
\hline LumbarTotal Z score & $-1.2 \pm 0.9$ & $0.01 \pm 0.08$ & $p<0.05$ \\
\hline Femur Total T score & $-1.6 \pm 0.9$ & $0.2 \pm 0.8$ & $p<0.05$ \\
\hline LumbarTotal T score & $-1.4 \pm 0.9$ & $0.4 \pm 0.1$ & $p<0.05$ \\
\hline BMD Lumbar & $0.8 \pm 0.1$ & $1.0 \pm 0.1$ & $p<0.05$ \\
\hline BMD Femur & $0.7 \pm 0.1$ & $0.8 \pm 0.1$ & $p<0.05$ \\
\hline
\end{tabular}

Table 3. The comparion of dialysis duration with some parameters in case group

\begin{tabular}{|l|l|l|}
\hline \multicolumn{2}{|c|}{} & Dialysis Duration \\
\hline IPTH & $r=0.3$ & $p<0.05$ \\
\hline$\beta_{2} m$ & $r=0.4$ & $p<0.05$ \\
\hline BMD $(F)$ & $r=-0.2$ & $p<0.05$ \\
\hline BMD $(L)$ & $r=0.1$ & $p>0.05$ \\
\hline BGP & $r=0.1$ & $p>0.05$ \\
\hline ALP & $r=0.4$ & $p<0.05$ \\
\hline
\end{tabular}

\section{Table 4. The distribution of radiological findings}

\begin{tabular}{|l|c|c|}
\hline Radiological Finding & $\%$ & Number of cases \\
\hline Osteopenia & $\% 80$ & 40 \\
\hline Subperiostal resorption & $\% 58$ & 29 \\
\hline Radial artery calcification & $\% 20$ & 10 \\
\hline Interdigital artery calcification & $\% 16$ & 8 \\
\hline Soft Tissue calcification & $\% 8$ & 4 \\
\hline Endosteal resorption & $\% 4$ & 2 \\
\hline
\end{tabular}

higher than $200 \mathrm{pg} / \mathrm{ml}$, we determined sensitivity as 93\% and specifity as $92 \%$. By such a similar evaluation, the sensitivity was $90.3 \%$ for high iPTH-BGP levels, whereas specifity was $87 \%$. In the presence of high $\mathrm{PPTH}$ values and the subperiosteal resorption, the sensitivity and specifity were found 83.9 and $84.2 \%$, respectively.

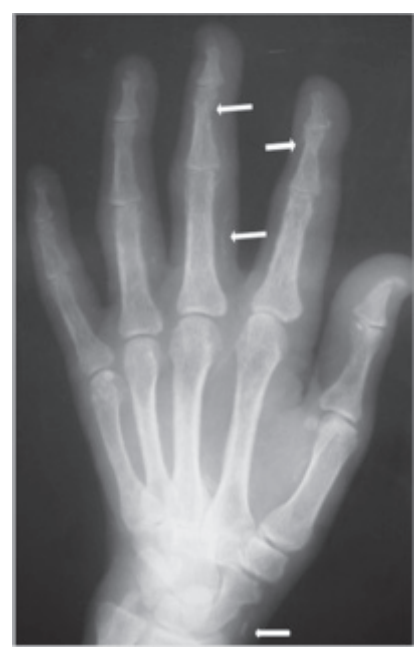

Figure 1. Right hand graphy of one of our case with evident osteopenia. Subperiostal resorption at radial side of middle phalanges of third finger and radioulnar side of middle phalanges of second finger are present. Interdigital artery calcification at radial side of third phalanges and radial artery calcification at wrist are seen.

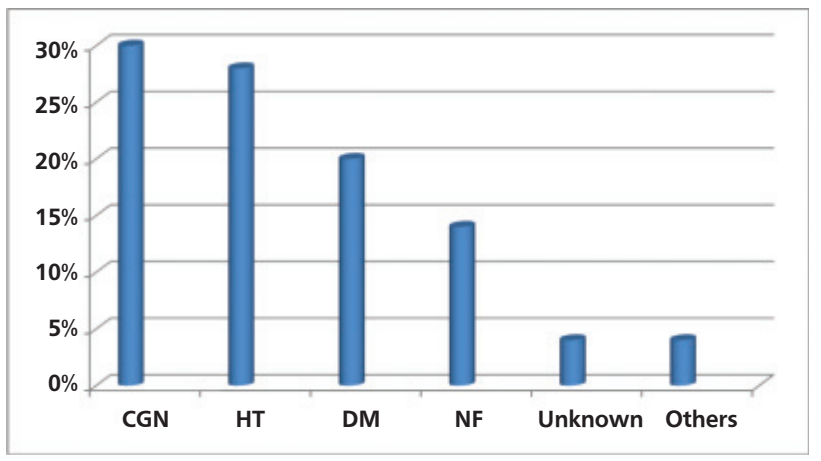

Graphic 1. The distribution of cases according to etiologies.

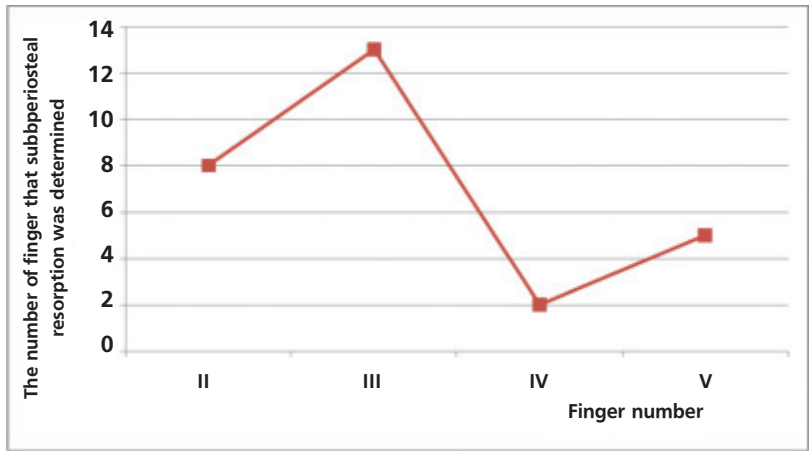

Graphic 2. The distribution of subperiostal resorption according to fingers. 


\section{Discussion}

RO; which is seen in patients with chronic renal failure; is a pathology that causes morbidity and disturbs the life quality. It was firstly defined by Liu and Chu in 1943. Osteitis fibrosa cystica, osteomalacia, adynamic bone disease $(\mathrm{ABH})$ and osteoporosis are the clinical components $(8,9,16,17)$.

In recent studies, it is mentioned that, bone loss on femur neck is higher than lumbar vertebra, because decrease in load at femur neck is more prevelant than lumbar vertebrae due to decreased physical activity $(10,11)$. It is known that risk of hip fracture is increased in hemodialysis patient when compared with normal population (12-14). Although no fracture was determined, the DEXA values of cases were found to be significantly lower than the control group $(p<0.05)$. Therefore, when the hemodialysis durations were compared with femur neck and lumbar vertebra, there was an inverse and weak relationship with femur neck BMD ( $r=-0.2)$. Because twelve postmenopausal subjects were present among women cases, effect of postmenopausal period on BMD values could not be ignored. This condition cause some limitations in this study. However, BMDF and BMDL T values of other 8 subjects which have regular menstrual period were respectively $-1,7$ and $-1,5$. On the other side, when all of the women subjects $(n=20)$ were evaluated it was seen that BMDF values were smaller than $B M D L$ values. This results support the effect of RO on BMD.

In the evaluation of secondary hyperparathyroidism, it was mentioned that the measure of $\mathrm{IPTH}$ values were found to be more sensitive, and it was shown that there was an inverse relationship between BMD and $\mathrm{PTTH}(10,15)$. Similarly, there was a inverse correlation between $\mathrm{PTH}$ and BMD values in our cases $(r=-0.4)$.

Serum level of BGP is accepted as indicator of bone formation. If the bone formation and degradation process is together in evaluated patients, it is accepted that BGP reflects the formation and degredation rates. It is also known that, decrease in clereance of BGP in patients with CRF may cause increase in serum BGP levels $(19,20)$. In our study, the BGP values of cases were found higher than control group, and the difference was found to be statistically significant $(p<0.05)$.

It is pointed out that $\mathrm{PTH}$ level is important in evaluation of RO (21). It has been shown that there is correlation between BGP level and IPTH level. Similarly, a significant correlation between IPTH and BGP was shown in case group ( $r=0.6)$. In our study, significant difference was determined between case and control groups in PTHH level $(p<0.05)$.

It is known that there is no correlation between serum ALP level and clinical types of RO (22). It is mentioned that ALP level is decreased with calcitriol therapy and this shows parallelism with decrease in PTH level. The ALP level was compared between case and control groups, and the difference was found to be statistically significant $(p<0.05)$. However, no correlation was determined between ALP and PTH in our case group.

In hemodialysis cases, $\beta_{2} \mathrm{~m}$; which accumulates within osteoarticular structures; is responsible for dialysis amiloidosis, and it frequently causes carpal tunnel syndrome and supraspinatus tendinitis. The relationships of $\beta_{2} \mathrm{~m}$ levels with hemodialysis duration and IPTH levels were shown $(23,24)$. In our study, significant difference was determined between cases and controls in $\beta_{2} \mathrm{~m}$ level $(p<0.05)$. Moderate positive correlations were found between $\beta_{2} \mathrm{~m}$ and hemodialysis duration, and between $\beta_{2} \mathrm{~m}$ and $\mathrm{PTH}$ in our case group $(r=0.4, r=0.5)$.

It was mentioned that, the bone changes that are caused by secondary hPTH are most frequently seen in hand bones $(25,26)$. When the graphies of dominant hands were evaluated in our case group, osteopenia was found in $80 \%$, subperiosteal resorption was found in 58\%, radial artery calcification was found in $20 \%$ and interdigital artery calcification was found in $16 \%$ and endosteal resorption was found in $4 \%$ of the patients. In our study, subperiosteal resorption was most frequently seen in third and second phalanges; respectively. It was prominent especially in radial side (Graphic 2).

Although bone biopsy is accepted as gold standart in classification of RO, the disadvantage of this method is being an invasive method $(27,28)$. A recent study; in which iPTH level was evaluated with radiologically evident erosions; the sensitivity, specifity and positive estimate value of iPTH levels over than 200 $\mathrm{pg} / \mathrm{ml}$ for the diagnosis of osteitis fibrosa cystica were found $83 \%, 88 \%$, and $88 \%$; respectively (29).

According to these findings, we determined the sensitivity and specifity related with the diagnosis of RO in our cases with iPTH levels over than $200 \mathrm{pg} / \mathrm{ml}$ (31 cases) and in our cases with osteopenia (40 cases) as $93 \%$ and $92 \%$; respectively. By such a similar evaluation, the sensitivity was $90.3 \%$ for high $\mathrm{iPTH}-$ BGP levels, whereas spasifity was $87 \%$. When the high IPTH and the presence of subperiosteal resorption was evaluated the sensitivity and specifity were found 83.9 and $84.2 \%$, respectively.

\section{Conclusion}

We are opinion that when osteopenia and subperiosteal resorption detected radiologically and high IPTH values with high BGP values in CRF cases were evaluated, RO diagnosis related with secondary hPTH may be foreseen. For that purpose, measure of $\mathrm{PPTH}, \mathrm{BMD}, \mathrm{BGP}$ and evaluation of hand graphies may be used in early diagnosis and follow-up of RO.

\section{References}

1. Lach F, Bover J. Renal Osteodystrophy. In: Brenner BM, Rector FC, editors. Textbook of Nephrology 1996; 2: 2187-2254.

2. Brenner BM, Lazarus M. Chronic Renal Failure. In: Isebocher $\mathrm{K}_{\text {, }}$ Braunwarld E, editors. Harrison's Principles of Internal Medicine. McGraw-Hill 1994;2:1274-81

3. Gonzalez EA, Martin KJ. Renal osteodystrophy: pathogenesis and management. Nephrol Dial Transplant 1995;10:13-21.

4. Ott SM. Bone histomorphometry in renal osteodystrophy. Semin Nephrol 2009;29: 122-32

5. Gal-Moscovici A, Popovtzer MM. New worldwide trends in presentation of renal osteodystrophy and its relationship to parathyroid hormone levels. Clin Nephrol 2005;63:284-9.

6. Tsukamoto Y. Kidney and bone update : the 5-year history 
and future of CKD-MBD. Bone biopsy and histomorphometrical analysis. Clin Calcium 2012;22:1019-24.

7. Seyrek $N$. The following up and management of renal osteodystrophy in dialysis patients. Turkiye Klinikleri J Int Med Sci 2006;2:55-62.

8. K/DOQI clinical practice guidelines for bone metabolism and disease in chronic kidney disease. Am J Kidney Dis 2003;42:51-2.

9. Martin KJ, Olgaard K, Coburn JW, Coen GM, Fukagawa M, Langman $C$, et al. Diagnosis, assessment, and treatment of bone turnover abnormalities in renal osteodystrophy. Am J Kidney Dis 2004;43:558-65.

10. Asaka M, lida H, Entani C, Fujita M, Izumino K, Takata M, et al: Total and regional bone mineral density by dual photon absorptiometry in patients on maintenance hemodialysis. Clinical Nephrol 1992;38:149-53.

11. Rizzoli R, Slosman D, Bonjour JP. The role of dual energy X-ray absorptiometry of lumbar spine and proximal femur in the diagnosis and follow-up of osteoporosis. Am J Med 1995;98:33-6.

12. Roschger $P$, Paschalis $E P$, Fratzl $P$, Klaushofer $K$. Bone mineralization density distribution in health and disease. Bone 2008;42:456-66.

13. Miller PD. Bone density and markers of bone turnover in predicting fracture risk and how changes in these measures predict fracture risk reduction. Curr Osteoporo Rep 2005;3:103-10.

14. Miller PD, Hochberg MC, Wehren LE, Ross PD, Wasnich RD. How useful are measures of BMD and bone turnover? Curr Med Res Opin 2005;21:545-54.

15. Rahimian M, Sami R, Behzad F. Evaluation of secondary hyperparathyroidism in patients undergoing hemodialysis. Saudi J Kidney Dis Transpl 2008;19:116-9.

16. Moe S, Drüeke T, Cunningham J, Goodman W, Martin K, Olgaard K, et al. Definition, evaluation, and classification of renal osteodystrophy: a position statement from Kidney Disease: Improving Global Outcomes (KDIGO). Kidney Int 2006;69:1945-53

17. Miller PD. Fragility fractures in chronic kidney disease: an opinionbased approach. Cleve Clin J Med 2009;76:715-21.

18. Hardy P, Benoit J, Donneaud B, Jehanno P, Lortat-Jacob Pathological fractures of the femoral neck in hemodialyzed patients. Apropos of 26 cases. Rev Chir Orthop Reparatrice Appar Mot 1994; 80:702-10.

19. Meier C, Seibel MJ, Kraenzlin ME. Use of bone turnover markers in the real world: are we there yet? I Bone Mineçr Res 2009;24:386-8.

20. Lehmann G, Ott U, Kaemmerer D, Schuetze J, Wolf G. Bone histomorphometry and biochemical markers of bone turnover in patients with chronic kidney disease Stages 3 - 5. Clin Nephrol 2008; 70:296-305.

21. Moe SM, Drüeke T. Improving global outcomes in mineral and bone disorders. Clin J Am Soc Nephrol 2008;3:127-30.

22. Suchowierska E, Mysliwiec M. Mineral and bone disturbances associated with chronic kidney disease. Pol Merkur Lekarski 2010;28:138-43.

23. Dervisoglu E, Anik Y, Erdogan S, Akansel G, Yilmaz A. Beta2microglobulin amyloidosis in hemodialysis and peritoneal dialysis patients. Ther Apher Dial 2008;12:306-10.

24. Barisic I, Ljutic D, Vlak T, Bekavac J, Peric I, Mise K, et al. Beta2microglobuline plasma level and painful shoulder in haemodialysed patients. Coll Antropol 2010;34:315-20.

25. Jevtic V. Imaging of renal osteodystrophy. Eur J Radiol 2003;46:85-95.

26. Roe S, Cassidy MJ. Diagnosis and monitoring of renal osteodystrophy. Curr Opin Nephrol Hypertens 2000;9:675-81.

27. Miller PD. The role of bone biopsy in patients with chronic renal failure. Clin J Am Soc Nephrol 2008;3:140-50.

28. Eastwood JB. Quantitative bone histology in 38 patients with advanced renal failure. J Clin Pathol 1982;35:125-34.

29. Pena YT, Soyibo AK, McGrowder D, Clarke TR, Barton EN. The importance of bone biomarkers in the diagnosis of renal osteodystrophy. West Indian Med J 2010;59:332-7. 